\title{
Standardization of Storage Conditions and Duration on Picroside-I and Picroside-II in Raw Material of Drug Kutki (Picrorhiza kurroa Royle ex Benth.)
}

Parbat Raj Thani" , \& Yash Pal Sharma

Dr. Y. S. Parmar University of Forestry and Horticulture, College of Forestry, Department of Forest Products, Nauni, Solan, Himachal Pradesh 173230, India

\section{KEYWORDS}

Degradation; Picrorhiza kurroa; picroside-I; picroside-II; storage

Tel: +977 83524375

E-mail:parbatkawa123@gmail.com

\section{Article History}

Received 10 March 2016

Revised 19 June 2016

Accepted 08 August 2016

Academic Editor

Gan B. Bajracharya

\section{\#CORRESPONDENCE}

\begin{abstract}
The study of the proper storage of medicinal plants after being harvested becomes necessary to minimize the loss of active constituents from microbial reactions, heat, moisture, light and enzymes etc. In the present study, fresh rhizomes of Picrorhiza kurroa (Kutki) were collected from $2600 \mathrm{~m}$ to $3300 \mathrm{~m}$ altitude of Himachal Pradesh (Rohtang area), India. The harvested material was washed to remove soil and other adhering materials, and then cut into small pieces and dried under shade. The air dried samples were packed in the different packing materials (i.e. Gunny bags or poly bags), stored either at room temperature or in refrigerator at $4^{\circ}$ to $6{ }^{\circ} \mathrm{C}$ or in humid environment $\left(85 \%\right.$ humidity and $\left.25^{\circ} \mathrm{C}\right)$ for different storage durations and then analyzed their chemical constituents bimonthly. The study showed that the content of picroside-I and picroside-II decreased with the increase in storage duration irrespective of storage condition. However, the loss in picroside-I and picroside-II with storage was maximum when "Kutki" samples were stored under humid condition ( $85 \%$ humidity, $25^{\circ} \mathrm{C}$ ) and minimum loss was observed when samples were stored at low temperature $\left(4-6{ }^{\circ} \mathrm{C}\right)$. So, to minimize the loss of picroside-I and picroside-II content in the drug Kutki during storage, Kutki must be stored at low temperature.
\end{abstract}

\section{Introduction}

Medicinal properties of plants are manifested due to the presence of bioactive compounds present in them and the diverse chemical nature of the active principles present in different plants accounts for their different biological and pharmacological properties. Depending upon the chemical structures, some of the active constituents are found stable, whereas others are unstable. Till the time of drying, storage and processing, the active constituents in the harvested plant/ plant part remain in contact with the microbial reactions, heat, moisture, light, solvents and enzymes etc., and some of these compounds undergo degradation. Therefore, after being harvested the medicinal plants at their proper growth and development stage when there is maximum contents of bioactive compounds on them are required to be carefully dried and stored under controlled conditions to minimize the loss of active constituents during drying conditions and storage of dried material till it is finally converted into formulation to be used by the consumers. Storage becomes necessary because many times the herb cannot be immediately processed either due to the processing site being far off or because of heavy rush of the raw material at the processing unit.

In the harvested material, many enzymatic reactions still keep on going in the presence of moisture under normal temperature (Patil and Laloraya 1983), and therefore requiring suitable containers for storage of dried herbs. Light sensitive compounds are required to be stored in dark, whereas, heat sensitive compounds should be stored at low temperature.

Due to lack of knowledge in appropriate storage conditions and time period for Picrorhiza kurroa to get optimum benefit, desired compounds from it has been disintegrated in the present situation. No specific studies on stability of iridoid glycosides (picroside-I and picroside-II) of plant P. kurroa under effect of different storage conditions and storage durations have been done, however; some related studies have been made to some extent in other medicinal plants.

Swiatek et al. (1988) analyzed one year old stored and fresh roots of Gentiana lutea and observed a higher amount of free phenolic acids in the stored material than in the freshly harvested roots. Brockmann et al. (1974) suggested keeping of the powdered material of Hypericum perforatum in dark to avoid decomposition of light sensitive bioactive compounds. Bomme (1997) recommended immediate drying of harvested crop of $\mathrm{H}$. perforatum at $40-60{ }^{\circ} \mathrm{C}$ to avoid loss of active compounds in the post-harvest period. Franke et al. (1999) observed significant decrease in the content of flavone glycosides at higher drying temperatures of $H$. perforatum, however within the range of $40-80^{\circ} \mathrm{C}$, biapigenins, hypericin and pseudohypericin as well as hyperforin were not substantially influenced by the different drying temperatures.

Chapelle and Denoel (1972) observed rapid degradation of valtrate (a bioactive compound) in valerian drug. However under usual preservative conditions, degradation was found minimum when powdered root was preserved under vacuum, low temperature, low humidity and under exposure to light. Lutomski and Turowska (1973) observed significant effect of storage periods and relative humidity on contents of essential oil and valepotrianes (bioactive compounds) in valerian drug samples. The essential oil content was reduced to $50 \%$ after six months of storage, whereas, degradation degrees of total valepotriates at relative humidities of $100,90,80$, 70 and $60 \%$ were $100,100,50,32.9$ and $15.7 \%$, respectively 
when the powdered roots of Valeriana officinalis were stored for six months. Lutomski et al. (1976) observed decrease in valepotriates content in proportion to increased drying temperature when Valeriana rhizomes were dried from 20$100{ }^{\circ} \mathrm{C}$ in laboratory without forced air flow. The optimum drying temperature was found to be $32-35^{\circ} \mathrm{C}$. Highest content of valepotriates was obtained at drying temperature of 60 ${ }^{\circ} \mathrm{C}$ with the air flow reaching $0.05 \mathrm{~m} 3 / \mathrm{min}$. Storage of crude drug resulted in significant loss in valepotriates. Verbist and Monnet (1975) have recommended immediate processing of fruits of Solanum xanthocarpum to avoid loss of solasodine during storage period.

Keeping in view of finding a best method of storage condition and storage duration for the raw material of $P$. kurroa, the present investigation was carried out.

\section{Materials and Methods 2.1. Collection and storage of raw material}

Fresh roots and rhizomes of $P$. kurroa were collected from 2600 m to3300 m altitude of Himachal Pradesh (Rohtangarea), India in 2012. The specimen of the plant material was submitted and authenticated at Department of Forest Products, Dr. Y. S. Parmar University of Forestry and Horticulture, Solan, India. The harvested material was washed with water to remove soil and other adhering materials and then cut into small pieces and dried under shade. The air dried samples (20 g each) were packed in the different packing materials (i.e. gunny bags or poly bags) and stored either at room temperature or in a refrigerator at $4^{\circ}$ to $6^{\circ} \mathrm{C}$ or in humid environment $(85 \%$ humidity and $25^{\circ} \mathrm{C}$ ) for different storage durations as stated below:

\section{(A) Storage conditions: 5}

(1) Gunny bag and storage at room temperature; (2) Gunny bag and storage in refrigerator at $4^{\circ}$ to $6{ }^{\circ} \mathrm{C}$; (3) Gunny bag and storage under humid condition ( $85 \%$ humidity and $25^{\circ} \mathrm{C}$ ); (4) Transparent polybag (closed) and storage at room temperature; and (5) Black polybag (closed) and storage at room temperature.

\section{(B) Storage durations: 8}

(1) Zero day (at the time of storage); (2) Two months; (3) Four months; (4) Six months; (5) Eight months; (6) Ten months; (7) Twelve months; and (8) Fourteen months.

\subsection{Extract preparation}

Table 1. Effect of different storage conditions of rhizomes of drug "Kutki" on picroside-I content (\%)

\begin{tabular}{|c|c|c|c|c|c|c|c|c|c|}
\hline Storage Durations & $\begin{array}{l}\text { o } \\
\text { day }\end{array}$ & $\begin{array}{l}2 \\
\text { months }\end{array}$ & $\begin{array}{l}4 \\
\text { months }\end{array}$ & $\begin{array}{l}6 \\
\text { months }\end{array}$ & $\begin{array}{l}8 \\
\text { months }\end{array}$ & $\begin{array}{l}10 \\
\text { months }\end{array}$ & $\begin{array}{l}12 \\
\text { months }\end{array}$ & $\begin{array}{l}14 \\
\text { months }\end{array}$ & $\begin{array}{l}\text { Mean } \\
\text { A }\end{array}$ \\
\hline \multicolumn{10}{|l|}{ Storage Conditions } \\
\hline \multirow[t]{2}{*}{ Gunny bag (room temperature) } & 6.827 & 6.67 & 6.462 & 6.362 & 6.255 & 6.08 & 5.887 & 5.65 & 6.274 \\
\hline & -2.798 & -2.77 & -2.732 & -2.713 & -2.694 & -2.661 & -2.624 & -2.579 & -2.696 \\
\hline \multirow[t]{2}{*}{ Gunny bag (maximum humidity) } & 6.827 & 0.638 & 0.353 & 0.108 & 0.1 & 0.015 & 0.006 & 0 & 1.006 \\
\hline & -2.798 & -1.28 & -1.163 & -1.053 & -1.049 & -1.008 & -1.003 & -1 & -1.294 \\
\hline \multirow[t]{2}{*}{ Black sealed poly bag } & 6.827 & 6.801 & 6.782 & 6.657 & 6.57 & 6.467 & 6.349 & 6.163 & 6.577 \\
\hline & -2.798 & -2.793 & -2.79 & -2.767 & -2.751 & -2.733 & -2.711 & -2.676 & -2.752 \\
\hline \multirow[t]{2}{*}{ Transparent sealed poly bag } & 6.827 & 6.788 & 6.672 & 6.537 & 6.525 & 6.361 & 6.171 & 5.962 & 6.48 \\
\hline & -2.798 & -2.791 & -2.77 & -2.745 & -2.743 & -2.713 & -2.678 & -2.639 & -2.735 \\
\hline \multirow[t]{2}{*}{ Gunny bag (refrigerated condition) } & 6.827 & 6.811 & 6.799 & 6.781 & 6.777 & 6.759 & 6.748 & 6.726 & 6.779 \\
\hline & -2.798 & -2.795 & -2.793 & -2.789 & -2.789 & -2.786 & -2.784 & -2.78 & -2.789 \\
\hline \multirow[t]{2}{*}{ Mean B } & 6.827 & 5.541 & 5.414 & 5.289 & 5.245 & 5.136 & 5.032 & 4.9 & \\
\hline & -2.798 & -2.485 & -2.449 & -2.414 & -2.405 & -2.38 & -2.36 & -2.335 & \\
\hline
\end{tabular}

Values in parentheses are transformed values using transformed values.
After completion of each storage period, stored material was taken out of packing, dried to a constant weight in an oven at $50{ }^{\circ} \mathrm{C}$ and then ground to form a uniform powder. Accurately weighed powdered plant material ( $2 \mathrm{~g}$ ) was subjected to Soxhlet extraction for $24 \mathrm{hrs}$ using methanol. After extraction, the solvent was distilled off and obtained residue was dried to a constant weight under vacuum.

\subsection{Quantitative estimation of picroside-I and picroside-II in the extracts using High Performance Liquid Chromatography (HPLC)}

Picroside-I and picroside-II were quantified in the extracts using HPLC (Water's binary HPLC unit with Waters HPLC pump 515 and dual $\lambda$ absorbance detector 2487) on column Sunfire C-18 $(4.6 \times 250 \mathrm{~mm}, 5 \mu \mathrm{m})$. Mobile phase consisted of methanol:water (40:60) with the flow rate of $0.9 \mathrm{ml} / \mathrm{min}$. Temperature was maintained at $24 \pm 1{ }^{\circ} \mathrm{C}$.

Each dried extract residue was 1000 times diluted with mobile phase, filtered through the membrane filter and $20 \mu \mathrm{l}$ of each sample was injected in HPLC. Area under curve of peaks of picroside-I and picroside-II was recorded at 270 $\mathrm{nm}$ wavelength on the basis of retention time comparing with that of standard picroside-I and picroside-II. Their contents in the extracts were quantified on the basis of area of the peak.

Percentage of picroside-I and picroside-II in each sample was calculated by using the following formula where percent purity of standard compound was taken as $95 \%$ :

Picrosides content $(\%)$

$$
=\frac{\text { Test Area }}{\text { Standard } \Lambda \text { rea }} \times \frac{\text { Weight of Standard }}{\text { Standard Dilution }} \times \frac{\text { Test Dilution }}{\text { Test Woight }} \times 100 \times \% \text { purity }
$$

The experiment was conducted under factorial Complete Randomized Design with two replications. Analysis of variance was worked out and critical difference at $5 \%$ of significance was calculated. The data was analyzed by using OPSTAT software.

\section{Results and Discussion}

All the samples stored under five different storage conditions were analyzed at bimonthly interval to check the effect on picroside-I and picroside-II contents with storage duration. The results were found statistically significant and are presented in Tables 1-4. Significant differences were observed under different storage conditions and durations on 
Table 2. Effect of different storage conditions of rhizomes of drug "Kutki" on picroside-II content (\%)

\begin{tabular}{|c|c|c|c|c|c|c|c|c|c|}
\hline Storage Durations & $\begin{array}{l}0 \\
\text { day }\end{array}$ & $\begin{array}{l}2 \\
\text { months }\end{array}$ & $\begin{array}{l}4 \\
\text { months }\end{array}$ & $\begin{array}{l}6 \\
\text { months }\end{array}$ & $\begin{array}{l}8 \\
\text { months }\end{array}$ & $\begin{array}{l}10 \\
\text { months }\end{array}$ & $\begin{array}{l}12 \\
\text { months }\end{array}$ & $\begin{array}{l}14 \\
\text { months }\end{array}$ & $\begin{array}{l}\text { Mean } \\
\text { A }\end{array}$ \\
\hline \multicolumn{10}{|l|}{ Storage Conditions } \\
\hline \multirow[t]{2}{*}{ Gunny bag (room temperature) } & 5.021 & 4.93 & 4.83 & 4.676 & 4.529 & 4.449 & 4.326 & 4.235 & 4.624 \\
\hline & -2.454 & -2.435 & -2.415 & -2.382 & -2.351 & -2.334 & -2.308 & -2.288 & -2.371 \\
\hline \multirow[t]{2}{*}{ Gunny bag (maximum humidity) } & 5.021 & 0.289 & 0.177 & 0 & 0 & 0 & 0 & 0 & 0.686 \\
\hline & -2.454 & -1.135 & -1.085 & -1 & -1 & -1 & -1 & -1 & -1.209 \\
\hline \multirow[t]{2}{*}{ Black sealed poly bag } & 5.021 & 4.962 & 4.895 & 4.793 & 4.643 & 4.531 & 4.417 & 4.353 & 4.702 \\
\hline & -2.454 & -2.442 & -2.428 & -2.407 & -2.376 & -2.352 & -2.328 & -2.314 & -2.387 \\
\hline \multirow[t]{2}{*}{ Transparent sealed poly bag } & 5.021 & 4.935 & 4.863 & 4.645 & 4.57 & 4.493 & 4.382 & 4.272 & 4.648 \\
\hline & -2.454 & -2.436 & -2.421 & -2.376 & -2.36 & -2.344 & -2.32 & -2.296 & -2.376 \\
\hline \multirow[t]{2}{*}{ Gunny bag (refrigerated condition) } & 5.021 & 4.995 & 4.957 & 4.934 & 4.905 & 4.884 & 4.852 & 4.835 & 4.923 \\
\hline & -2.454 & -2.448 & -2.441 & -2.436 & -2.43 & -2.426 & -2.419 & -2.415 & -2.434 \\
\hline \multirow[t]{2}{*}{ Mean B } & 5.021 & 4.022 & 3.944 & 3.809 & 3.729 & 3.672 & 3.595 & 3.539 & \\
\hline & -2.454 & -2.179 & -2.158 & -2.12 & -2.103 & -2.091 & -2.075 & -2.063 & \\
\hline
\end{tabular}

Values in parentheses are transformed values using transformed values.

Table 3. Loss in picroside-I content (\%) during storage under different storage conditions

\begin{tabular}{|c|c|c|c|c|c|c|c|c|c|}
\hline Storage Durations & $\begin{array}{l}\circ \\
\text { day }\end{array}$ & $\begin{array}{l}2 \\
\text { months }\end{array}$ & $\begin{array}{l}4 \\
\text { months }\end{array}$ & $\begin{array}{l}6 \\
\text { months }\end{array}$ & $\begin{array}{l}8 \\
\text { months }\end{array}$ & $\begin{array}{l}10 \\
\text { months }\end{array}$ & $\begin{array}{l}12 \\
\text { months }\end{array}$ & $\begin{array}{l}14 \\
\text { months }\end{array}$ & $\begin{array}{l}\text { Mean } \\
\text { A }\end{array}$ \\
\hline \multicolumn{10}{|l|}{ Storage Conditions } \\
\hline \multirow[t]{2}{*}{ Gunny bag (room temperature) } & 5.021 & 4.93 & 4.83 & 4.676 & 4.529 & 4.449 & 4.326 & 4.235 & 4.624 \\
\hline & -2.454 & -2.435 & -2.415 & -2.382 & -2.351 & -2.334 & -2.308 & -2.288 & -2.371 \\
\hline \multirow[t]{2}{*}{ Gunny bag (maximum humidity) } & 5.021 & 0.289 & 0.177 & 0 & 0 & 0 & 0 & 0 & 0.686 \\
\hline & -2.454 & -1.135 & -1.085 & -1 & -1 & -1 & -1 & -1 & -1.209 \\
\hline \multirow[t]{2}{*}{ Black sealed poly bag } & 5.021 & 4.962 & 4.895 & 4.793 & 4.643 & 4.531 & 4.417 & 4.353 & 4.702 \\
\hline & -2.454 & -2.442 & -2.428 & -2.407 & -2.376 & -2.352 & -2.328 & -2.314 & -2.387 \\
\hline \multirow[t]{2}{*}{ Transparent sealed poly bag } & 5.021 & 4.935 & 4.863 & 4.645 & 4.57 & 4.493 & 4.382 & 4.272 & 4.648 \\
\hline & -2.454 & -2.436 & -2.421 & -2.376 & -2.36 & -2.344 & -2.32 & -2.296 & -2.376 \\
\hline \multirow[t]{2}{*}{ Gunny bag (refrigerated condition) } & 5.021 & 4.995 & 4.957 & 4.934 & 4.905 & 4.884 & 4.852 & 4.835 & 4.923 \\
\hline & -2.454 & -2.448 & -2.441 & -2.436 & -2.43 & -2.426 & -2.419 & -2.415 & -2.434 \\
\hline \multirow[t]{2}{*}{ Mean B } & 5.021 & 4.022 & 3.944 & 3.809 & 3.729 & 3.672 & 3.595 & 3.539 & \\
\hline & -2.454 & -2.179 & -2.158 & -2.12 & -2.103 & -2.091 & -2.075 & -2.063 & \\
\hline
\end{tabular}

Values in parentheses are transformed values using transformed values

Table 4. Loss in picroside-II content (\%) during storage under different storage conditions

\begin{tabular}{|c|c|c|c|c|c|c|c|c|c|}
\hline Storage Conditions & $\begin{array}{l}0_{\text {day }} \\
\text { da }\end{array}$ & $\begin{array}{l}2 \\
\text { months }\end{array}$ & $\begin{array}{l}4 \\
\text { months }\end{array}$ & $\begin{array}{l}6 \\
\text { months }\end{array}$ & $\begin{array}{l}8 \\
\text { months }\end{array}$ & $\begin{array}{l}10 \\
\text { months }\end{array}$ & $\begin{array}{l}12 \\
\text { months }\end{array}$ & $\begin{array}{l}14 \\
\text { months }\end{array}$ & $\begin{array}{l}\text { Mean } \\
\text { A }\end{array}$ \\
\hline \multirow[t]{2}{*}{ Gunny bag (room temperature) } & 0 & 1.805 & 3.797 & 6.858 & 9.801 & 11.378 & 13.833 & 15.644 & 7.889 \\
\hline & -1 & -1.673 & -2.189 & -2.798 & -3.286 & -3.518 & -3.85 & -4.079 & -2.799 \\
\hline \multirow[t]{2}{*}{ Gunny bag (maximum humidity) } & 0 & 94.25 & 96.482 & 100 & 100 & 100 & 100 & 100 & 86.341 \\
\hline & -1 & -9.76 & -9.873 & -10.05 & -10.05 & -10.05 & -10.05 & -10.05 & -8.86 \\
\hline \multirow[t]{2}{*}{ Black sealed poly bag } & ० & 1.156 & 2.509 & 4.527 & 7.511 & 9.751 & 12.012 & 13.307 & 6.347 \\
\hline & -1 & -1.429 & -1.873 & -2.35 & -2.917 & -3.279 & -3.605 & -3.782 & -2.529 \\
\hline \multirow[t]{2}{*}{ Transparent sealed poly bag } & ० & 1.708 & 3.131 & 7.485 & 8.976 & 10.506 & 12.715 & 14.913 & 7.429 \\
\hline & -1 & -1.643 & -2.032 & -2.909 & -3.156 & -3.392 & -3.702 & -3.989 & -2.728 \\
\hline \multirow[t]{2}{*}{ Gunny bag (refrigerated condition) $\circ$} & 0 & .513 & 1.274 & 1.735 & 2.305 & 2.71 & 3.365 & 3.703 & 1.951 \\
\hline & -1 & -1.158 & -1.505 & -1.653 & -1.8 & -1.917 & -2.089 & -2.162 & -1.661 \\
\hline \multirow[t]{2}{*}{ Mean B } & ० & 19.886 & 21.439 & 24.121 & 25.718 & 26.869 & 28.385 & 29.513 & \\
\hline & -1 & -3.132 & -3.495 & -3.952 & -4.242 & -4.431 & -4.659 & -4.812 & \\
\hline
\end{tabular}

picroside-I content (Table 1 ). The initial value of picroside-I content $(6.827 \%)$ recorded at the time of storage of the material decreased after 14 months of storage to $5.650 \%$ in gunny bag (room temperature), nil in gunny bag ( $85 \%$ relative humidity), $6.163 \%$ in black sealed poly bag, $5.962 \%$ in transparent sealed poly bag and $6.726 \%$ in gunny bag (refrigerated condition). Among different storage conditions, maximum mean value of picroside-I content (6.779\%) was found in gunny bag (refrigerated condition) and minimum value (1.006\%) was recorded in gunny bag ( $85 \%$ relative humidity).

Under all storage conditions, picroside-II content decreased with storage durations (Table 2). The initial value of picroside-II content recorded as $5.021 \%$ at the time of storage of material, decreased after 14 months to $4.235 \%$ in gunny bag (room temperature), nil in gunny bag ( $85 \%$ relative humidity), $4.353 \%$ in black sealed poly bag, $4.272 \%$ in transparent sealed poly bag and $4.835 \%$ in gunny bag (refrigerated condition). Among different storage conditions, maximum mean value of picroside-II content (4.923\%) was found in gunny bag (refrigerated condition) and minimum value $(0.686 \%)$ was recorded in gunny bag (maximum humidity). 
The analysis of stored samples showed the loss in picroside-I and picroside-II contents increased with increase in storage duration but the quantum of loss varied under different storage conditions (Tables 3 and 4). The results show that though both picroside-I and picrosideII contents decreased with storage duration under all the storage conditions, however, storage of Kutki rhizome at maximum humidity (85\%) and at temperature $25^{\circ} \mathrm{C}$ recorded complete loss of picroside-I (in 14 months) and picroside-II (in 6 months) suggesting that raw material of Kutki should not be kept under humid condition after drying. The loss in picroside-I and picroside-II contents was minimum when raw material was stored at low temperature which suggests that if raw material of Kutki is required to be stored for long duration then it should be stored at low temperature.

\section{Conclusion}

During storage, picroside-I and picroside-II contents decrease with different storage conditions and durations. Therefore, to minimize the loss of these bioactive compounds in the drug "Kutki" during storage, it must be stored at low temperature.

\section{References}

Bomme, U. 1997. Technology of field production of perforated St. John's Wort. (Hypericum perforatum L.). Zeitschrift fur Arznei and Gewurzpflanzen 2:127-134.

Brockmann, H., U. Franssen, D. Spitzner, and H.
Augustiniak. 1974. Zur isolierung und Konstitution des pseudohypericins. Tetrahedron Letters 15:1991-1994.

Chapelle, J. P., and A. Denoel. 1972. Valepotriates in Valeriana officinalis roots. Page 16 in R. B. H. Wills and D. Shohet. Production of high quality Australian valerian products. Rural Industries Research and Development Corporation, Australia.

Franke, R., R. Schenk, U. Bauermann. 1999. Variability in Hypericum perforatum L.breedinglines.Acta Horticulturae(ISHS)502:167-174.

Lutomski, J., and M. Turowska. 1973. Effect of relative humidity on the content of valepotrianes and volatile oil in Valeriana officinalis. Herba Polonica 9(4):338-341.

Lutomski, J., W. Debska, and B. Okulicz Kozarynowa. 1976. Investigations on the valepotriates of Valeriana officinalis roots. Herba Hungarica 15(2):13-21.

Patil, S., and M. M. Laloraya. 1983. Effect of drying conditions on the solasodine content of Solanum viarum berries. Current science 52:252-254.

Swiatek, L., E. Dombrowicz, and R. Zadernowski. 1988. Phenolic acid content in Gentiana lutea L. roots. Herba polonica 34(1-2):15-20.

Verbist, J. F., and R. Monnet. 1975. Study of the steroid alkaloids of Solanum xanthocarpum. IV. Effect of postharvest treatments on the solasodine content of the fruit. Plantes medicinales en Phytotherapie 9:69-71. 